\title{
Measurement of static and dynamic properties of municipal solid waste at Mavallipura landfill site, India
}

\author{
B. P. Naveen * (D)
}

\author{
${ }^{*}$ Correspondence: \\ bpnaveen@ggn.amity.edu \\ Department of Civil \\ Engineering, Amity \\ School of Engineering \\ and Technology, Amity \\ University Gurgaon, \\ Manesar 122413, Haryana, \\ India
}

\begin{abstract}
Municipal solid waste (MSW) landfills have been widely constructed around the world for proper dispose of MSW. Geotechnical properties of MSW are difficult to determine because the heterogeneity, wide variation in particle size distribution and time dependent degradation. Knowledge of geotechnical properties of MSW is essential for the design and operation of landfills. Geotechnical properties of the MSW from landfills is very limited. The design of MSW landfills requires the selection of representative MSW material properties. Static and dynamic properties of emplaced MSW from landfill sites at Bangalore, India are evaluated. A comprehensive field and laboratory studies are conducted on MSW disposed at Mavallipura landfills that are in operation for about 12 years. Laboratory studies included: waste composition, water content, hydraulic conductivity, shear behavior for evaluation of static MSW properties. Field measurements included: cyclic plate load test and geophysical testing (multichannel analysis of surface waves) to assess the dynamic MSW properties at landfill site. Also, results obtained from cyclic plate load test is compared with numerical simulation like PLAXIS 2D. In additional, this paper presents a method for extrapolation of $\mathrm{Vs}_{30}$ for MSW site where subsurface data does not extend to a depth of $30 \mathrm{~m}$. Based on the detailed field and laboratory test data, characterization of the small strain shear modulus and the shear wave velocity of MSW is an integral component of various seismic analyses, including site classification, analysis seismic response of landfill. The results in this study will provide guidance in the design and operation of the landfills in India.
\end{abstract}

Keywords: Geotechnical properties, Cyclic triaxial, Ultrasonic, Plate load test, Municipal solid waste, Landfill

\section{Introduction}

Globally the estimated quantity of wastes generation was about 12 billion tonnes (BT) in the year 2002 of which $11 \mathrm{BT}$ were industrial wastes, and 1.6 BT were municipal solid wastes [1]. While many attempts have been made to make use of industrial waste for geotechnical application, not many studies have made on municipal solid waste. Geotechnical properties of municipal solid waste assume great importance in their reuse, disposal as well as reclamation of waste dumps sites/landfills. Evaluation of geotechnical properties of municipal solid waste has been difficult due to their heterogeneity and time-dependent degradation. Evaluation of geotechnical properties of MSW is carried 
out through in situ, laboratory tests and back analysis of field performance data. The results of the laboratory tests have implication for both geoenvironmental engineering practice and for research. Refinement of the knowledge base of engineering parameters for MSW may assist in the safe, environmentally responsible design and operation of existing and future landfill. To reclaim the old dump sites/closed landfill sites for infrastructural development, it is necessary to know their geotechnical characteristics. The characteristics of waste change with time due to their degradation. Closed landfill waste mostly represents the characteristics of highly degraded wastes. Its mechanical behavior is of paramount importance in obtaining a safe and economical design [2]. MSW is known to be a heterogeneous material of varying constituent types and dimensions, containing elements that degrade with time. To consider MSW as a geo-material supporting the foundation of structures such as buildings and pavement, an analysis of the bearing capacity of the foundation and further long-term settlement of MSW as well as the basic geotechnical properties is necessary [3].

In current days, dynamic properties of municipal solid waste are evaluated in the laboratory. However, laboratory tests have several challenges and disadvantages. Recovering undisturbed samples of MSW is not feasible in laboratory tests. Hence testing apparatus and MSW samples also need to be large to accommodate large waste particles that are not available [4], Therefore, an Insitu testing method is ideal to evaluate dynamic properties of MSW is very promising and attractive.

For the design of landfill and seismic analysis, including seismic displacement estimation and site response analysis, need MSW properties. In the analysis major important input parameters include the dynamic properties of MSW are: the shear wave velocity or small-strain shear modulus, material damping ratio, shear modulus reduction versus shear strain. In additional other input parameters for the analysis are Poisson's ratio, MSW unit weight and dynamic shear strength. The above mentioned dynamic properties can significantly influence the site-specific seismic response of landfills and it is critical to characterize and envisage the dynamic properties of municipal solid waste.

Several researchers have been documented and characterized the dynamic properties of soil deposits and rocks. Literature suggests that the great number of investigators have estimated the dynamic properties of soil deposits and rocks using variety of methods, including laboratory testing (e.g. Hardin and Black [5], Peacock and Seed [6], Seed and Idriss [7], Dyvik and Madshus [8], Vucetic and Dobry [9], and Darendeli [10]) and field testing (Nazarin and Stoke [11], Cox [12], Rosenblad et al. [13]). The advantage of the laboratory testing is that boundary conditions are well defined and testing parameters can be easy controlled. The major drawbacks of the laboratory test method are inconsistency of stress state between laboratory sample and the material in field. Field testing is not affected by the sample disturbance and the results obtained from the in situ field testing incorporate the complexity of the actual stress state. But this method is costly, time consuming and incapable of controlling some test parameters like drainage control and boundary condition. It requires a comprehensive understanding of the in situ testing methodologies. Both field and laboratory methods have been used to estimate the dynamic properties of MSW, to the author's understanding, very limited studies have been carried out to estimate the static and dynamic properties of MSW in field and laboratory. Hence, a comprehensive geotechnical laboratory \& in situ dynamic properties of 
MSW study has been taken up to study their engineering properties of MSW from Mavallipura landfill site.

\section{Materials and methods}

\section{Study area}

Mavallipura landfill site has been selected for detailed study for characterization, potential for contamination and to explore methods of improving their geotechnical behaviour. Mavallipura landfill site is about 100 acres located in Mavallipura and about 35 acres is used for landfill (Fig. 1).

The landfill was operated by M/s Ramky Environmental Engineers opened in 2007 can sustain about 600 tons of waste. However, the Bruhat Bengaluru Mahanagara Palike (BBMP) has been sending almost 1000 tons of garbage from Bangalore city every day. Citizens around Mavallipura village demand that the landfill site must be stopped immediately as it is illegal and unscientifically managed and thus it is now closed for land filling.

\section{MSW sample collection}

The MSW sample used in this study is the composted MSW reject collected from the Mavallipura landfill site, Bengaluru. The composted reject had particle sizes $35 \mathrm{~mm}$ to $4 \mathrm{~mm}$. Composted MSW is then shifted to coarse segregation area having mechanical arrangements to segregate the rejects like plastic, cloth, metals, a glass of the size above $14 \mathrm{~mm}$ using rotary screen (trommel) of $35 \mathrm{~mm}$ and $15 \mathrm{~mm}$ sizes. Feeder, hopper and conveyor belts are provided with trommel for taking away rejects and semi-finished compost separately. Above semi-finished compost is then further shifted to curing section for further digestion. After curing, compost is shifted to refinement section that consists of vibratory screen or trommel of 4-6 mm size. Disposal of reject material (reject material like gravels, sand, stones, glass, metal and other inert materials above $4 \mathrm{~mm}$ are separated in this section). This reject material goes to landfill. Figure 2 shows the dry waste at the landfill site. From this heap, sufficient quantity of dry waste is collected and kept in the closed bags and carried to the laboratory for testing. Determination of geotechnical properties of MSW is very difficult due to the heterogeneity and a wide variety of particles in MSW.

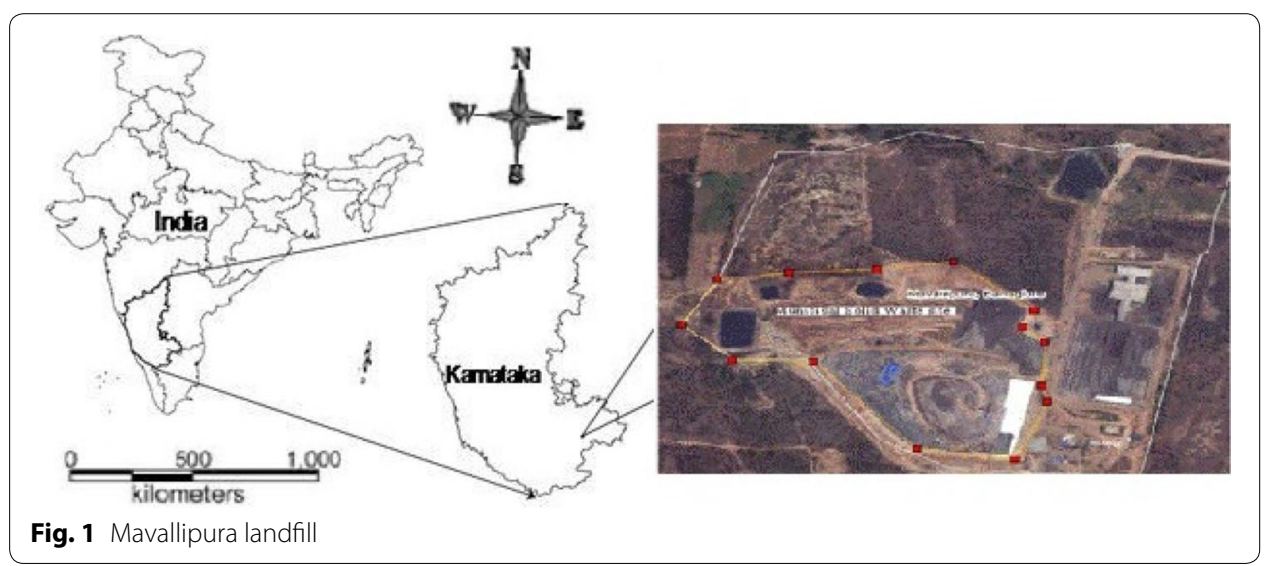




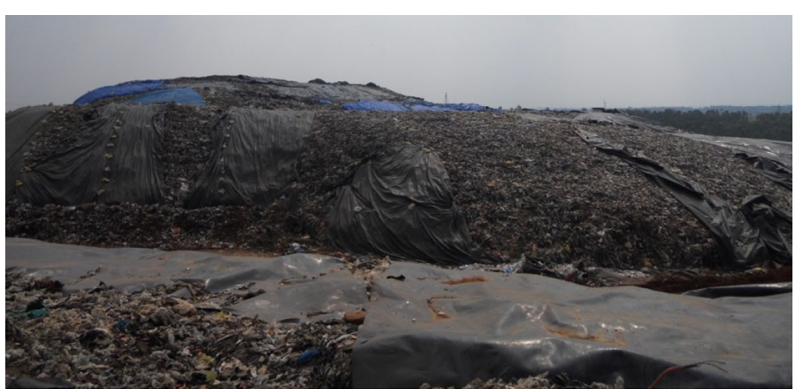

Fig. 2 Scenario of municipal solid waste in Mavallipura landfill

The particle size of land filled MSW components is too large to conduct the geotechnical properties in a laboratory test, hence the component of the land filled MSW is cut with scissors/crushed to a certain volume before the preparation of MSW samples.

A representative sample of the MSW is one that contains a subset of all the constituents of an MSW in a landfill in the same proportion as they are present in the target solid waste landfill.

- The sample is spread on the floor and thoroughly mixed by mechanical shovel.

- The sample is then placed in a uniform pile of approximately $0.8 \mathrm{~m}$ high in a square box.

- The uniform pile is divided into four quarters using straight lines perpendicular to each other.

- A portion of the sample is collected from all the quadrants to have a representative sample.

- The process is repeated until the desired representative sample size i.e.10-20 kg is obtained.

\section{Solid waste composition}

Random manual sampling methods applied in this study and used to identify the MSW composition. MSW composition mainly depends on the several factors such as cultural traditions, food habits, socio-economic and climatic conditions. It also varies from place to place. The study was carried in Mavallipura landfill site with $100 \mathrm{~kg}$ MSW sample. The collected MSW sample is sorted physically in various ingredients such as paper, fiber, metals, soils, glass, and miscellaneous waste on a sorting platform. The individual components are separated and weighed. The weights are then expressed as a percentage of the original sample. The observed MSW composition as paper $22 \%$, yard waste (garden waste) $10 \%$ plastic, $35 \%$ metals and glass $17 \%$, wood $6 \%$ and miscellaneous waste (including textile, rubber, leather, ash, soil, stone.etc. 10\% (Fig. 3). Under wet conditions, organic waste such as kitchen waste usually become unidentifiable 2 or 3 months after placement in the landfill. Consequently, the mass of these organic products, which has not been transformed to energy or gas, is accounted for as ash, soil, stone... etc. 


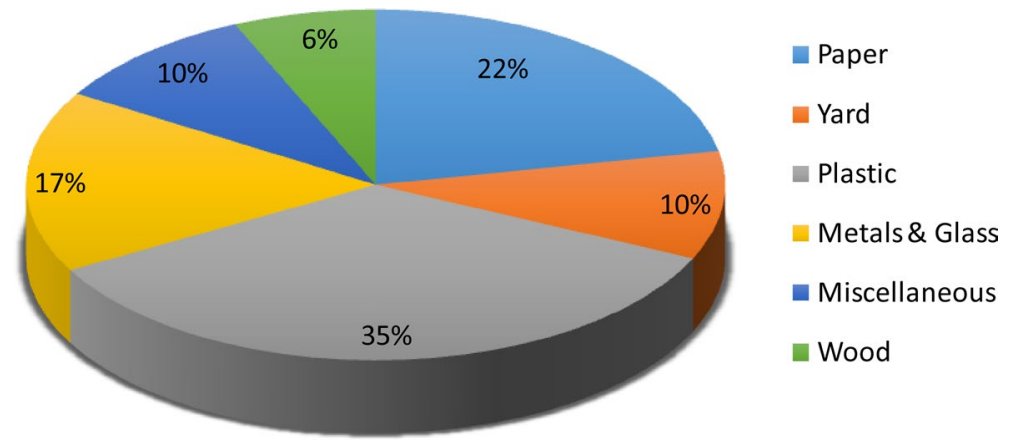

Fig. 3 MSW composition of Mavallipura landfill site

\section{Laboratory tests}

The various laboratory tests were conducted as per the standard procedure established by the American society for testing and materials to determine the physical and geotechnical properties of the MSW.

\section{Moisture content}

Moisture content is defined as dry gravimetric moisture content: the ratio of the mass of water in a waste sample to the mass of solids in the waste sample expressed as a percentage. During the moisture content determinations, the temperature was maintained at $60{ }^{\circ} \mathrm{C}$ to avoid combustion of volatile materials.

The average moisture content of MSW is about 36\%, due to an operation carried out in a landfill. Zeiss and Major [14] reported that natural moisture content in wastes varies widely as a function of the time of year, the location of origin, the amount of rain, and amount of organic matter and has been reported to range from 20 to $72 \%$. Beaven and Powrie [15] has presented that after landfilling the moisture content of the waste may increase through absorption of water by certain components of the waste such as paper, cardboard and textiles.

\section{Specific gravity}

The specific gravity test was carried out as per ASTM D [16]. Specific gravity is the ratio of the mass of unit volume of waste at a stated temperature to the mass of the same volume of gas-free distilled water at a stated temperature. The average specific gravity of MSW obtained was about 1.15. The lower value of specific gravity can be attributed to the presence of decomposed organic matter. The specific gravity is a basic material property used in the design calculations of the landfill. Knowing the specific gravity of MSW makes it easier to evaluate the values of voids ratio, porosity and degree of saturation. Nazli et al. [17] reported specific gravity of MSW from the United States; found that the average specific gravity was 1.377 . Breitmeyer [18] determined the specific gravity of MSW landfill, United States, found that the 1.65. All the experiments were performed as per the standard procedure established by the American society for testing and materials. 


\section{Grain size distribution}

The particle size distribution test was carried out as per ASTM D [19]. The particle size distribution of waste constituents in the MSW is important because of its significance in the design of mechanical separators and shredder and waste treatment process. This particle size distribution varies widely. The mechanical behavior and decomposition of MSW are strongly influenced by the particle size distribution of the waste. Due to the presence of large particles and heterogeneity of the waste, the grain size distribution of MSW is extremely difficult to determine.

A set of one large sieves with opening diameters of 100, 50 and $20 \mathrm{~mm}$ were used to determine the gradation of waste collected from landfill. A particle size distribution curve describes the percentage by mass of particles of the different size ranges. The horizontal axis represents the particle size on a logarithmic scale. The vertical axis represents the percentage by weight of particles that are finer than a specific size on the horizontal axis. Figure 4 shows the typical gradation of MSW, and the MSW sample consisted of coarser particles with sizes ranging from 0.08 to $5 \mathrm{~mm}$, but approximately $85 \%$ by weight basis of waste particles with sizes less than $10 \mathrm{~mm}$. These results show that greater amounts of finer materials were present in the landfilled waste, which may be due to degradation of waste as well as the presence of daily cover soil.

\section{Compaction test}

Standard proctor compaction tests were carried out as per ASTM D [20]. The compaction curve of MSW sample shows a maximum dry density (MDD) of $7.0 \mathrm{kN} / \mathrm{m}^{3}$ at an optimum moisture content of $50 \%$ (Fig. 5). The results indicate that the maximum dry density may be achieved if the moisture content of the waste is increased near to the optimum compaction content of about $50 \%$. The compaction characteristics of waste are close to the average values of MDD of $7.1 \mathrm{kN} / \mathrm{m}^{3}$ and OMC of $58 \%$ obtained by Harris [21] for a landfill MSW in England.

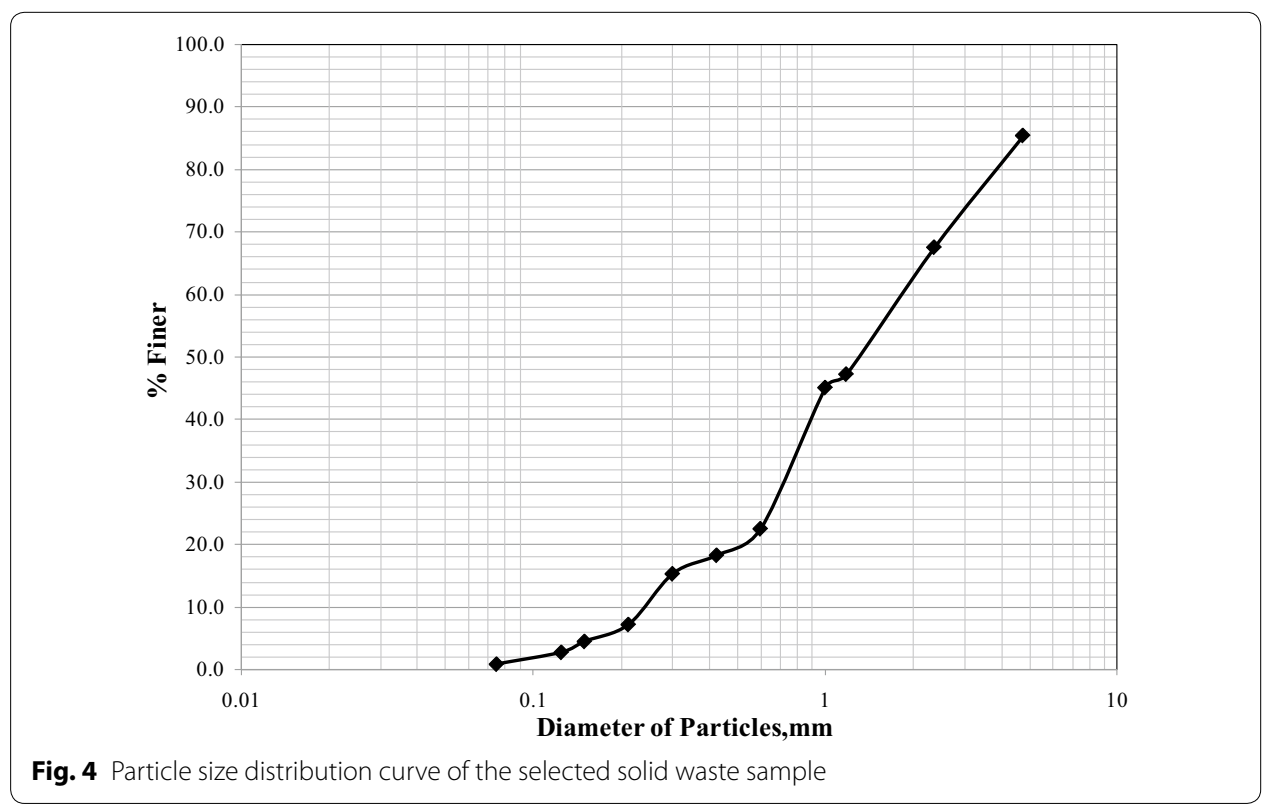




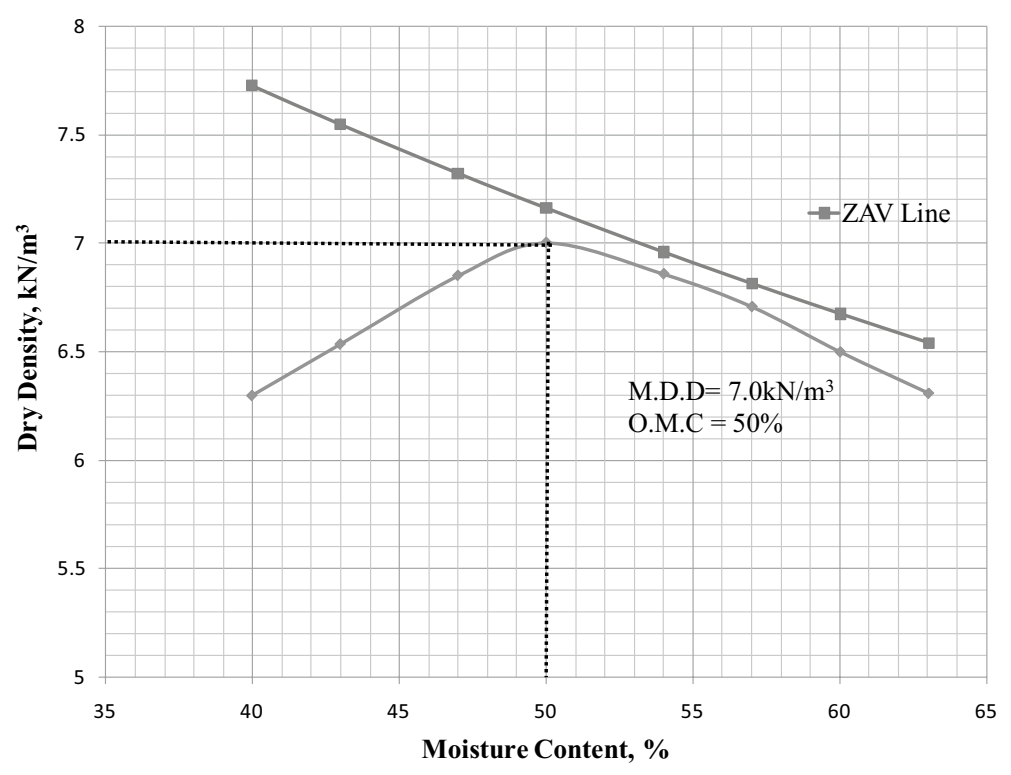

Fig. 5 MSW compaction curve

\section{Permeability test}

Constant head hydraulic conductivity tests carried out as per ASTM D [22]. The permeability of MSW is $4 \times 10^{-4} \mathrm{~cm} / \mathrm{s}$, and it corroborates with results reported by others in the literature. Kumar and Sahadat [23] reported that change in permeability might be due to the particle disintegration with decomposition and the resulting increase in the percentage of finer fraction. With the increase in the percentage of finer fraction, there might be a significant change in pore size, geometry and continuity resulting in the decrease of fluid flow.

Korman et al. [24] indicated higher values of permeability of MSW, which might be attributed to the heterogeneity and reconstitution of the sample in the laboratory. With degradation the particle size of the degradable constituent in MSW was expected to decrease which might significantly influence the permeability of MSW. When the coefficient is higher than about $10^{-4} \mathrm{~cm} / \mathrm{s}$ the material is considered selfdraining, whereas coefficients lower than $10^{-9} \mathrm{~cm} / \mathrm{s}$ are considered impervious.

\section{Compressibility test}

Compressibility tests carried out as per ASTM D [25]. Pressure versus void ratio(e$\log \sigma)$ curves for each sample were obtained. Pressure-void ratio curve is plotted on a semi-logarithmic scale with effective pressure as the abscissa on the logarithmic scale and void ratio as the ordinate on an arithmetic scale, the virgin curve becomes a straight line. The compression index represents the slope of the linear section of the pressure-void ratio curve and remains constant within a fairly large range of pressures.

Pressure versus void ratio relationship for MSW is shown in Fig. 6. The calculated values of compression index $\left(C_{c}\right)$ is 0.47 and recompression index $\left(C_{s}\right)$ of MSW is 0.095 , Coefficient of compressibility $\mathrm{a}_{\mathrm{v}}\left(\mathrm{m}^{2} / \mathrm{kN}\right)$ is $1.2 \times 10^{-3}$, Coefficient of volume 


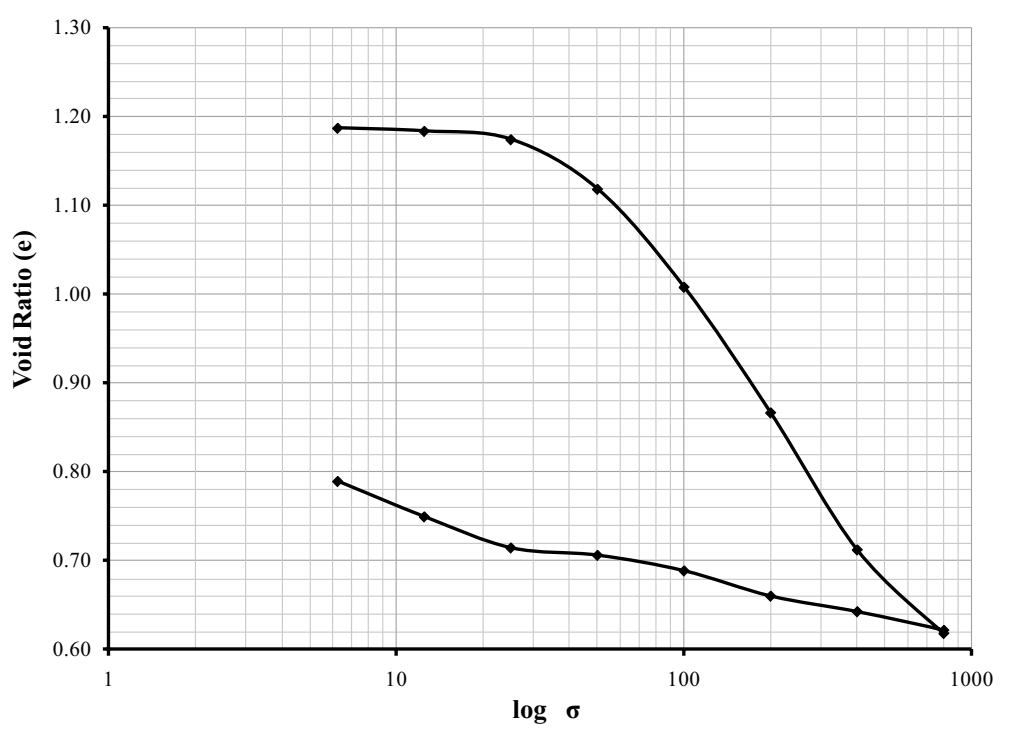

Fig. 6 e vs. $\log \sigma$ curve

compressibility $\mathrm{m}_{\mathrm{v}}\left(\mathrm{m}^{2} / \mathrm{kN}\right)$ is $5.5 \times 10^{-4}$. Reddy et al. [26] conducted laboratory testing on MSW landfill from the United States, found the compression index varying from 0.15 to 0.36 .

The secondary compression coefficient $\left(C_{\alpha}\right)$ were determined from the slope of the straight-line portion of compression versus log time plot (Fig. 8) beyond the primary consolidation, the secondary compression coefficient $\left(C_{\alpha}\right)$ values found to be 0.071 . Hossain et al. [27] has conducted laboratory tests for MSW and showed that the compression index varies from 0.16 to 0.37 , and secondary compression coefficient $\left(C_{\alpha}\right)$ varied between 0.02 and 0.07 . Thus, the values obtained in this study are in very good agreement with values reported earlier elsewhere.

\section{Direct shear test}

Direct shear tests carried out as per ASTM D [28]. During this study, the MSW sample exhibited continuous strength gain with an increase in shear strain (16\%) to define strength. At present, there is no standard cut-off displacement value is used to define MSW shear strength. Based on the literature often uses 10-20\% deformation is used to define MSW shear strength (Gabr and Valero [29]). Many researchers have observed and reported the behavior of MSW (Grisolia et al. [30]). Hence, it is recommended that the shear strength of MSW be displacement dependent. Figure 7a shows the shear stress versus horizontal displacement for MSW.

Figure $7 \mathrm{~b}$ shows the volumetric strain versus shear strain for MSW. From this graph we can observe MSW is getting continuously compressed due to breakage of particles. Hence there is no swelling/dilation. The shear strength parameters were calculated based on the Mohr-Coulomb failure criteria. Based on the analysis of the data, the cohesion of MSW was $10 \mathrm{kPa}$ and friction angle is $34^{\circ}$. The lower cohesion value of the Mavallipura landfill MSW specimen may be related to the type of fibrous 


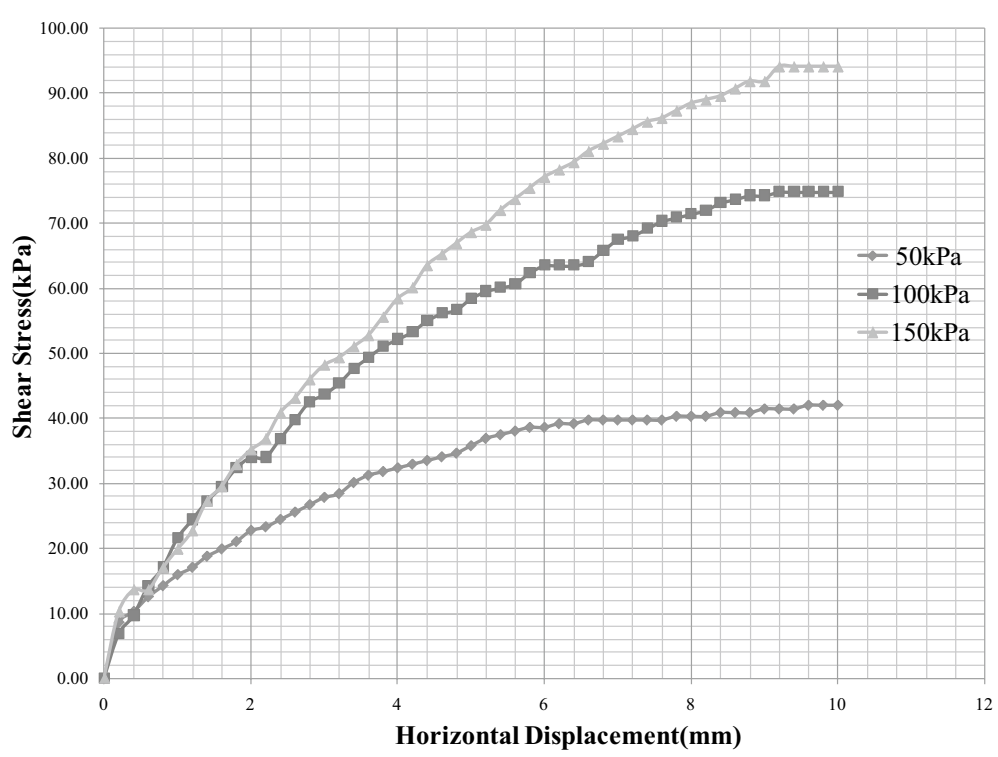

(a) Shear stress vs. Horizontal displacement

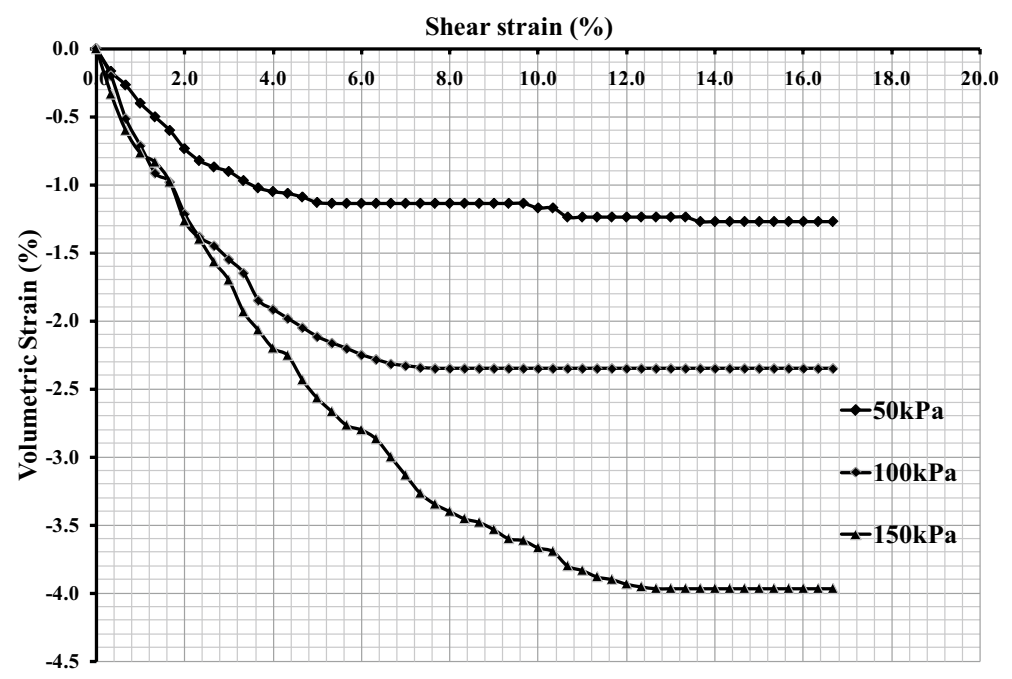

(b) Volumetric strain vs. shear strain

Fig. 7 Direct shear test results

material, mostly paper/cardboard that, in general, has a lower tensile strength than plastics, particularly if it is saturated.

Table 1 shows the direct shear test result of MSW. In MSW, sample exhibited continuous strength gain with an increase in shear strain. Due to interlocking of fibrous materials resulting in the development of cohesion within the MSW material with increasing strain. The fibrous elements mostly thin plastic and textiles, responsible for the reinforcing or the 'cohesive' component of strength. Further, the tensile strength of these fibrous materials will decrease with elapsed time due to decomposition processes. For waste similar to our results has been reported by Tony et al. [31]. The tests were conducted for waste and the cohesion mobilized at a strain level of $10 \%$ was 
Table 1 Results of direct shear test

\begin{tabular}{llll}
\hline Normal stress $(\mathbf{k P a})$ & Peak shear stress $(\mathbf{k P a})$ & $\boldsymbol{\emptyset}\left({ }^{\circ}\right)$ & $\mathbf{C}(\mathbf{k P a})$ \\
\hline 50 & 41.9 & 34 & 10 \\
100 & 74.8 & & \\
150 & 94.1 & & \\
\hline
\end{tabular}

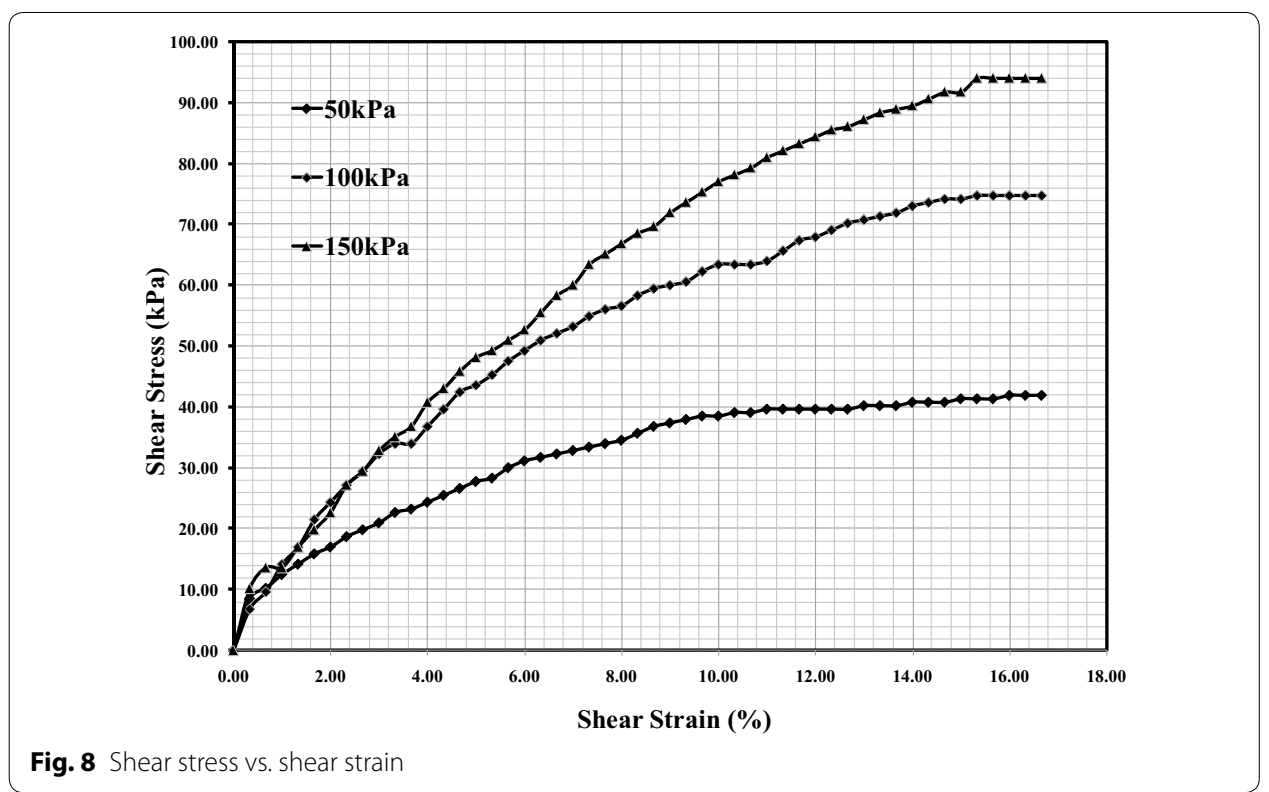

found to decrease from 23 to $0 \mathrm{kPa}$ and the mobilized friction angle at the same strain level increases from $9.9^{\circ}$ to $26^{\circ}$ Tony et al. [31]. Howland and Landva [32] conducted direct shear tests on MSW and the resulting shear strength properties reported $16 \mathrm{kPa}$ and $33^{\circ}$. Gabr and Valero [29] reported the shear strength properties ranged from 0 to $28 \mathrm{kPa}$ and $20-39^{\circ}$ for landfilled MSW. Reddy et al. [26] has reported based on direct shear tests, drained cohesion and friction angle were varied in the range of $12-64 \mathrm{kPa}$ and $31-35^{\circ}$ for a land filled MSW. Thus, the shear strength parameters obtained are within the range of values reported in the literature.

\section{Shear modulus from shear stress-shear strain curve}

The modulus and Poisson's ratio mainly depend on the drainage conditions and are estimated from experimental shear stress-shear strain relationships obtained from the direct shear test. At the initial stage of the shear, stress-shear strain curve is nearly linear dependence, but shear modulus strain of MSW is a very small due to the overall value of the strain of MSW. Since, the shear stress-shear strain behavior obtained is not linear (Fig. 8), an initial tangent modulus is selected.

The shear modulus (G) and elastic modulus (E) characterize the MSW stiffness as shown in Table 2. In MSW particles are closed packed, hence the modulus tends to be high this can be measured by the density. As the confining stress increases, the elastic 
Table 2 The elastic constants obtained from direct shear test

\begin{tabular}{lclc}
\hline Sample & Confining stress $(\mathbf{k P a})$ & $\mathbf{G}(\mathbf{M P a})$ & $\mathbf{E}(\mathbf{M P a})$ \\
\hline MSW & 50 & 0.698 & 1.815 \\
& 100 & 0.935 & 2.431 \\
& 150 & 0.940 & 2.444
\end{tabular}

constants increase for MSW. Based on the elastic constants results obtained from the direct shear test found to be very soft material.

\section{Triaxial test}

Triaxial tests carried out as per ASTM D [33]. The triaxial test is repeated on different MSW samples with different confining pressure (50 kPa, $100 \mathrm{kPa}, 150 \mathrm{kPa})$ and the results are interpreted by plotting the Mohr's circles as shown in Fig. 9. The minor principle stress $\left(\sigma_{3}\right)$ is the confining pressure and total stress $\left(\sigma_{1}-\sigma_{3}+\sigma_{3}\right)=\sigma_{1}$ is the major principal stress, horizontal and vertical planes are the principal planes. By plotting different Mohr's circles from different tests and common tangent to them gives the shear strength parameter cohesion $10 \mathrm{kPa}$ and friction angle was found to be $37^{\circ}$.

Table 3 shows the triaxial test result of MSW. In the triaxial test, the MSW sample exhibited continuous strength gain with an increase in axial strain. Frictional component is increased due to sliding and rolling of fibrous particles over one another resulting in the development of apparent cohesion due to interparticle bonds within the MSW material.

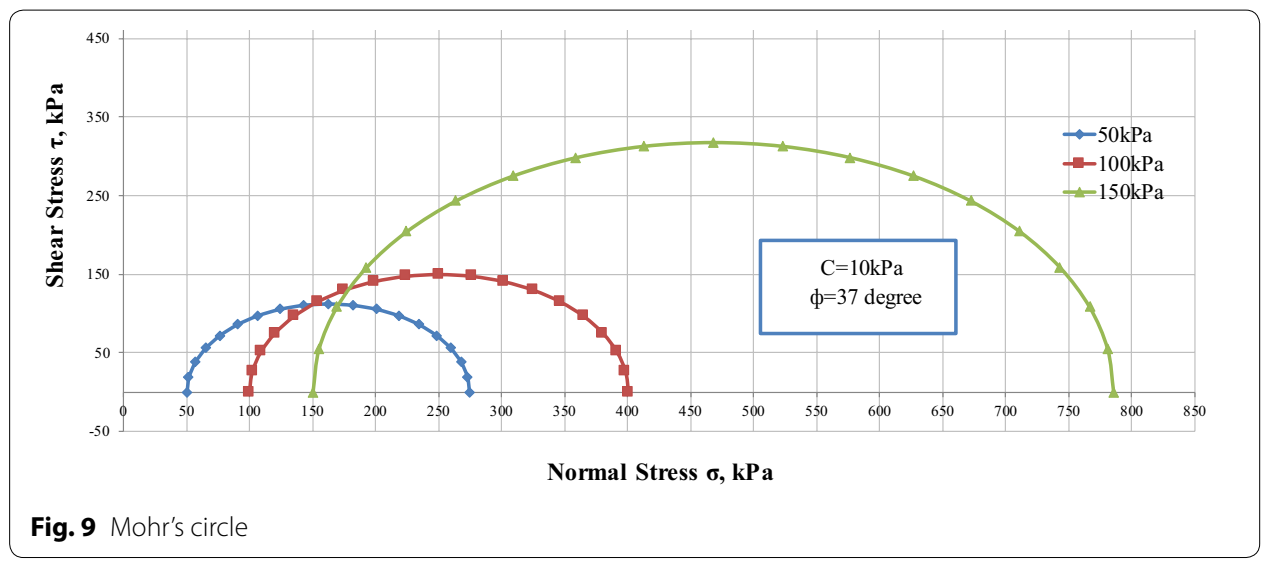

Table 3 Results of triaxial test

\begin{tabular}{llll}
\hline Normal stress $(\mathbf{k P a})$ & Peak deviatoric stress $(\mathbf{k P a})$ & $\boldsymbol{\emptyset}^{\left({ }^{\circ}\right)}$ & $\mathbf{C}(\mathbf{k P a})$ \\
\hline 50 & 224.49 & 37 & 10 \\
100 & 300.23 & & \\
150 & 635.58 & & \\
\hline
\end{tabular}




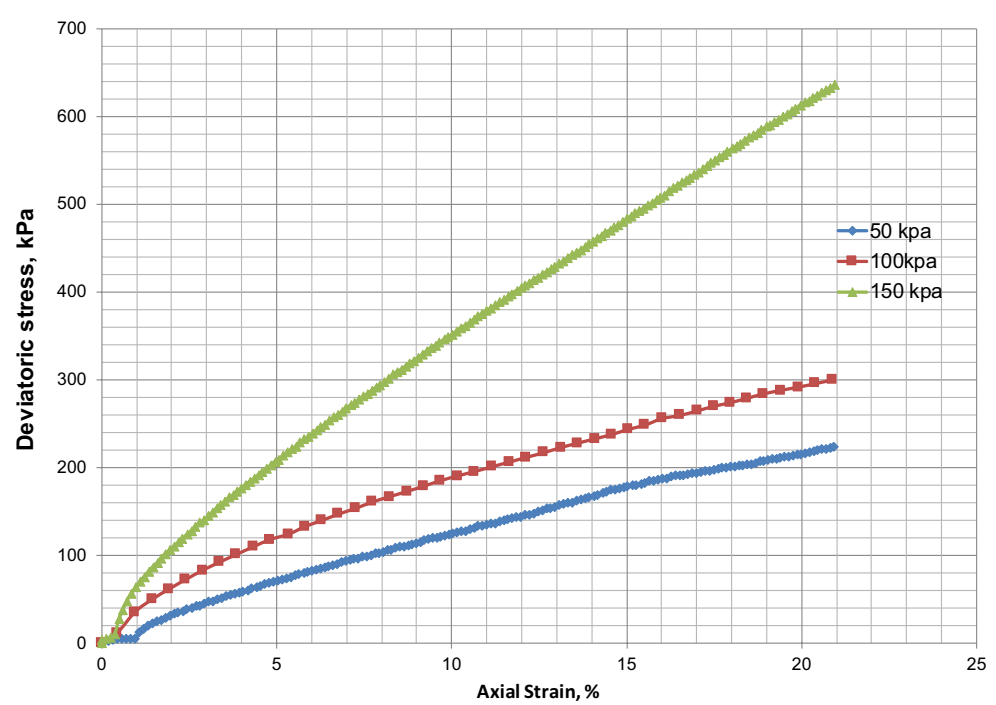

Fig. 10 Deviator stress vs. axial strain

Table 4 The elastic constants obtained from triaxial test

\begin{tabular}{llc}
\hline Confining stress $(\mathbf{k P a})$ & $\mathbf{G}(\mathbf{M P a})$ & $\mathbf{E}(\mathbf{M P a})$ \\
\hline 50 & 0.48 & 1.26 \\
100 & 1.12 & 2.25 \\
150 & 1.80 & 3.60 \\
\hline
\end{tabular}

\section{Elastic modulus from stress-strain curve}

Elastic materials are materials that return to their original configuration on unloading and obey Hooke's law. In a triaxial test with constant confining stress and increase deviator stress gives a direct measure of undrained modulus, $\mathrm{E}_{\mathrm{u}}$ is obtained from the undrained triaxial test data (Fig. 10), while drained test conditions, drained modulus $\mathrm{E}_{\mathrm{d}}$ is obtained.

Young's modulus decreases with increasing deviator stress, and at a peak of the stressstrain curve the tangent modulus becomes zero deviator stress. The deviator stress equal to $1 / 2$ or $1 / 3$ of the peak deviator stress (Lambe and Whitman [34],). Unconsolidated undrained triaxial tests data tends to produce a usable value of Secant modulus $\left(\mathrm{E}_{\mathrm{s}}\right)$, since any confining pressure (stiffness) of the MSW so that a secant modulus is obtained. At initial stage deviator, stress-axial strain curve is linear, but the elastic strain of MSW is a very small due to the overall value of the strain.

Table 4 shows the elastic constants obtained from the unconsolidated undrained triaxial test. An increase in the confining stress increase the elastic constants (elastic modulus and shear modulus) increases. The elastic constants values obtained from unconsolidated undrained triaxial test falls within the recommendations of stressstrain modulus $\left(\mathrm{E}_{\mathrm{s}}\right)$ (Gopal Ranjan and Rao [35]). The material is found to be very soft. 


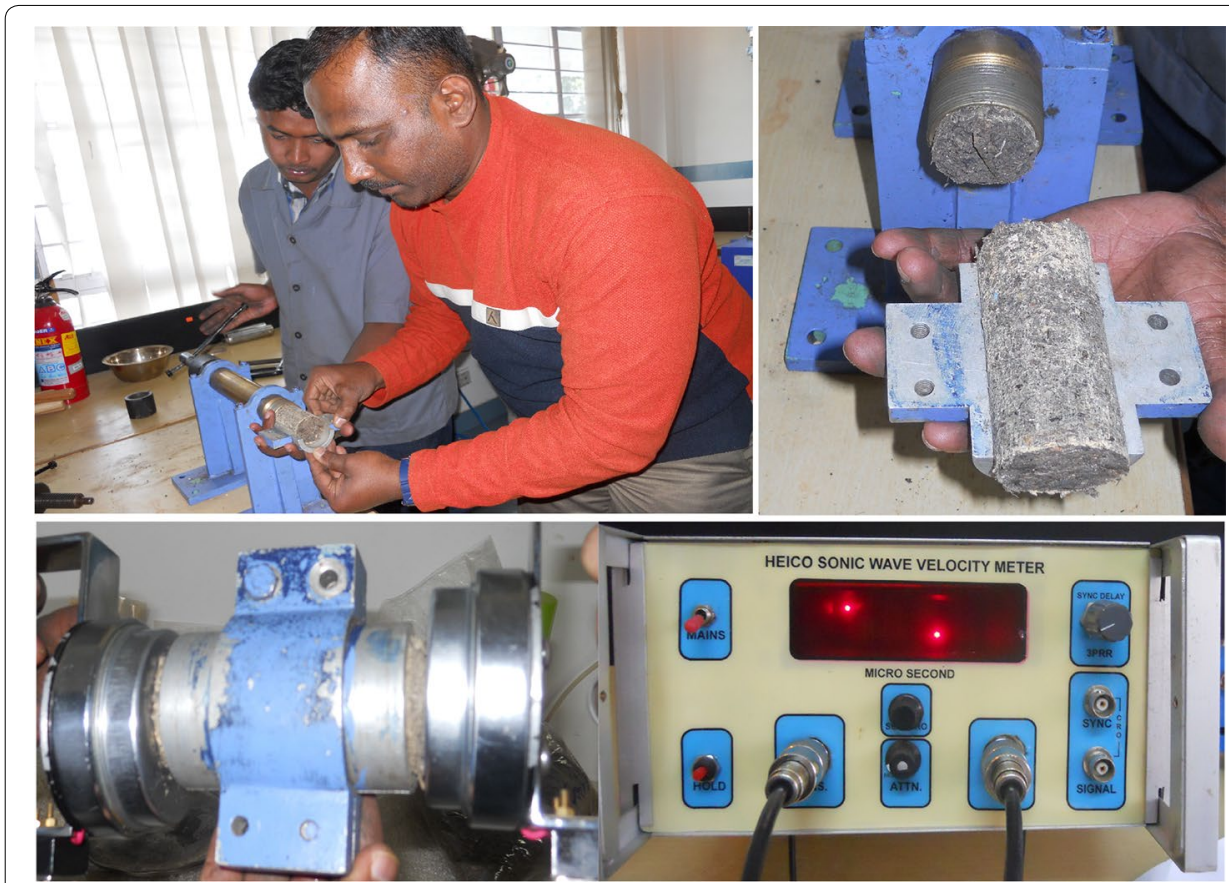

Fig. 11 Ultrasonic test setup

Table 5 The pulse velocities and elastic constants obtained from ultrasonic test

\begin{tabular}{lllllllr}
\hline $\begin{array}{l}\text { Density }(\mathbf{k N} / \\
\left.\mathbf{m}^{\mathbf{3}}\right)\end{array}$ & $\mathbf{T}_{\mathbf{p}}(\mathbf{s})$ & $\mathbf{T}_{\mathbf{s}}(\mathbf{s})$ & $\mathbf{V}_{\mathbf{p}}(\mathbf{m} / \mathbf{s})$ & $\mathbf{V s}(\mathbf{m} / \mathbf{s})$ & $\boldsymbol{\mu}$ & $\mathbf{E}(\mathbf{M P a})$ & $\mathbf{G}(\mathbf{M P a})$ \\
\hline 7 & 0.00099900 & 0.00118203 & 100 & 85 & 0.3 & 2.00 & 5.05 \\
8 & 0.00089000 & 0.00105306 & 112 & 95 & 0.3 & 3.14 & 7.22 \\
9 & 0.00070500 & 0.00083417 & 142 & 120 & 0.3 & 6.50 & 12.96 \\
\hline
\end{tabular}

\section{Pulse velocities and ultrasonic elastic constants}

The pulse velocities and ultrasonic elastic constants of MSW testing were carried out at different densities as per ASTM D [33]. Sample preparation is shown in Fig. 11.

The results obtained from the ultrasonic test clearly indicates that the with increase in density the sample became denser hence voids gets reduced, and $\mathrm{P}$ pulse propagation velocity $\left(V_{p}\right)$ increases. The elastic constants determined by the ultrasonic test method. Since the pulse frequencies used are above the audible range.

Table 5 shows the elastic constants obtained from the ultrasonic test. An increase in the density the shear wave velocity and elastic constants (elastic modulus and shear modulus) increases. The elastic constants values obtained from ultrasonic test shows higher values when to compare with the unconsolidated undrained triaxial test.

\section{Field tests}

\section{Seismic survey carried out in Mavallipura landfill site}

The Mavallipura landfill was surveyed up to a length of about $35 \mathrm{~m}$ at the top level. A total of eight boreholes consisted of uncompacted waste up to a depth $6 \mathrm{~m}$. Initially, 


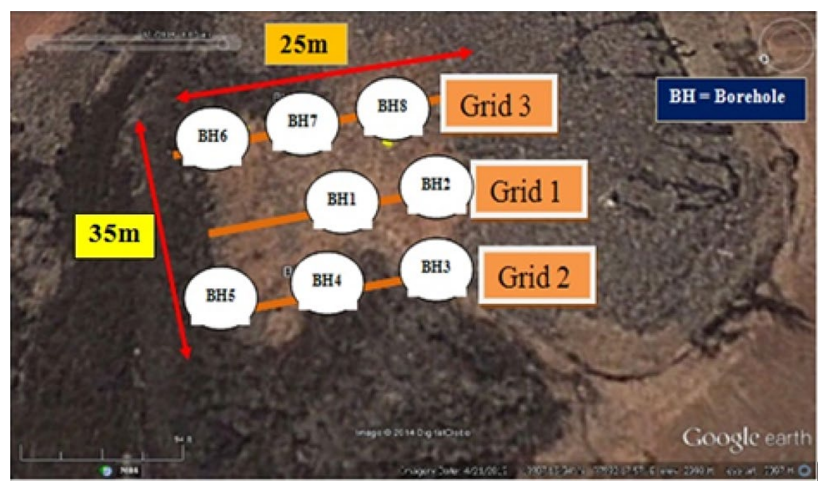

Fig. 12 Typical borehole locations in Mavallipura landfill

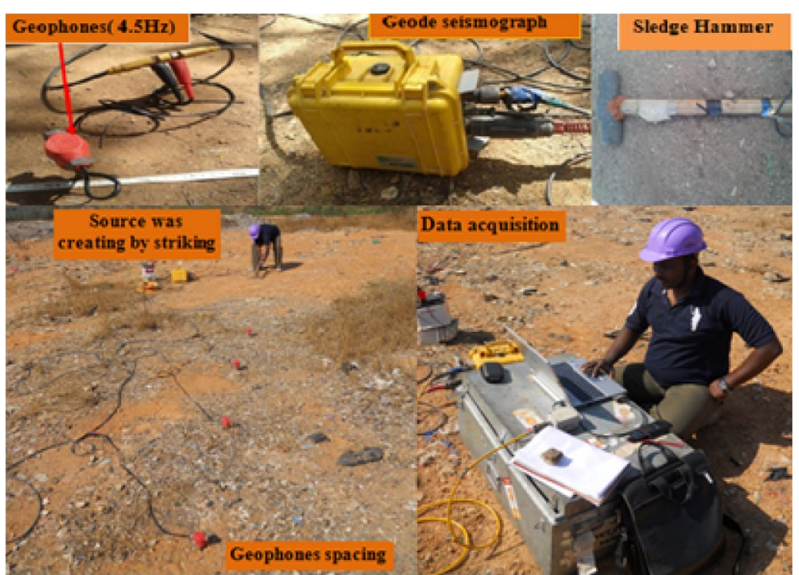

Fig. 13 MASW carried out in Mavallipura landfill

landfill area is divided into three grids. Grid one consists of two bore holes and grid two and grid three consists of three boreholes each (Fig. 12). The active one-dimensional MASW survey carried out the exact same place where eight borehole data is available. The typical MASW test setup used for the present study consists of 24-channel geode seismograph and 24 geophones of $4.5 \mathrm{~Hz}$ capacity. Seismic data were recorded using Geode seismograph, and seismic waves are created by the sledgehammer (5 kg) (Fig. 13) with $300 \mathrm{~mm} \times 300 \mathrm{~mm}$ size hammer plate with ten shots, geophones capture these seismic waves. The captured Rayleigh wave is further analysed using SurfSeis program developed by the Kansas Geological Survey.

The seismic survey can be used to measure the small-strain shear wave velocity $\left(\mathrm{V}_{\mathrm{s}}\right)$ for evaluating the dynamic properties of MSW in the subsurface. The shear wave velocity was used to characterize the MSW and assist in the selection of MSW material properties. The active one-dimensional MASW survey carried out the exact same place where eight borehole data is available. Figure 14 shows the shear wave velocity increases with depth from approximately 35 to $150 \mathrm{~m} / \mathrm{s}$.

Shear wave velocity $\left(V_{s}\right)$ and small-strain shear modulus $\left(G_{\max }\right)$ are important parameters in a broad spectrum of geotechnical engineering analyses, such as seismic response 
Naveen Geo-Engineering (2018)9:26

Page 15 of 22

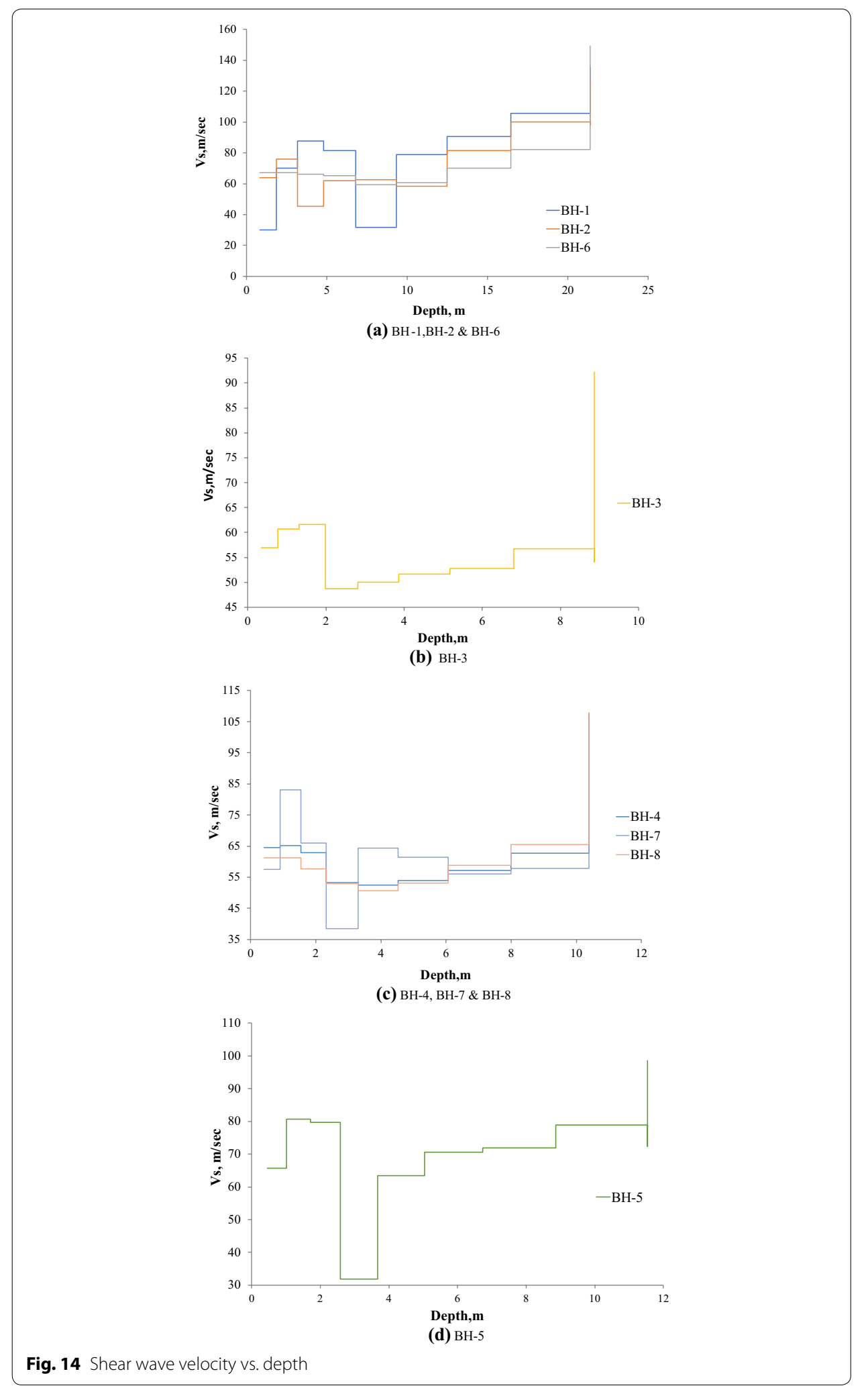


Table 6 Results obtained from MASW testing

\begin{tabular}{|c|c|c|c|c|c|}
\hline $\mathrm{BH}$ & $\begin{array}{l}\text { Maximum } \\
\text { depth }(m)\end{array}$ & Avg. $V_{s}(m / s)$ & $\begin{array}{l}\mathrm{G}_{\max }, \mathrm{GPa} \\
\text { for maximum depth }\end{array}$ & $\begin{array}{l}\text { Avg. } V_{s,} \mathrm{~m} / \mathrm{s} \\
\text { for depth } 30 \mathrm{~m}\end{array}$ & $\begin{array}{l}\mathrm{G}_{\text {max' }} \mathrm{GPa} \\
\text { for depth } \\
30 \mathrm{~m}\end{array}$ \\
\hline 1 & 21.37 & 83.17 & 0.048 & 90.54 & 0.057 \\
\hline 2 & 21.35 & 75.06 & 0.039 & 81.45 & 0.046 \\
\hline 3 & 8.86 & 54.21 & 0.020 & 76.80 & 0.041 \\
\hline 4 & 10.39 & 60.24 & 0.025 & 65.70 & 0.030 \\
\hline 5 & 11.54 & 67.01 & 0.031 & 70.25 & 0.034 \\
\hline 6 & 21.37 & 72.84 & 0.037 & 78.54 & 0.043 \\
\hline 7 & 10.39 & 59.73 & 0.025 & 65.73 & 0.030 \\
\hline 8 & 10.20 & 60.25 & 0.025 & 84.80 & 0.050 \\
\hline
\end{tabular}

analysis, machine foundation analysis, and soil-structure interaction analysis. These properties can also be used as an index of material characterization and are useful to assess settlement estimates. Equation 1 presents the relationship between the shear wave velocity and the small strain shear modulus.

$$
\mathrm{G}_{\text {max }}=\rho \times \mathrm{V}_{\mathrm{s}}^{2}
$$

where $\rho$ is the mass density.

Table 6 shows the Average values of shear wave velocity measured at the site. There different averages were estimated.

1. Avg. shear wave velocity over the measured depth;

2. Avg. shear wave velocity over the depth of $30 \mathrm{~m}$.

The $\mathrm{V}_{S 30}$ method provides only a single number for the average shear-wave velocity in the top $30 \mathrm{~m}$. Shear-wave velocity, $\mathrm{V}_{S}$, is an important parameter for evaluating dynamic behavior of MSW. $\mathrm{V}_{S}$ averaged over the top $30 \mathrm{~m}$ of MSW is referred to as $\mathrm{V}_{S 30}$. The NEHRP Provisions use $\mathrm{V}_{S 30}$ to classify the sites according to type of subsurface materials.

The NEHRP shear wave velocity $\left(\mathrm{V}_{\mathrm{s}}\right)$ assigned to the subsurface at a specific site is calculated using the following formula:

$$
\bar{V}_{s}=\frac{\sum_{i=1}^{n} d_{i}}{\sum_{i=1}^{n} \frac{d_{i}}{v_{s i}}}
$$

where $V_{s}=$ the NEHRP shear wave velocity; $V_{s i}=$ the shear wave velocity of any layer in $\mathrm{m} / \mathrm{s}$; di $=$ the thickness of any layer (between 0 and $30 \mathrm{~m}$ ).

Based on the MASW test results, site conditions were defined according to a geotechnical classification system used by NEHRP. Site type E corresponds to soft material and average shear wave velocity would be $<180 \mathrm{~m} / \mathrm{s}$. 


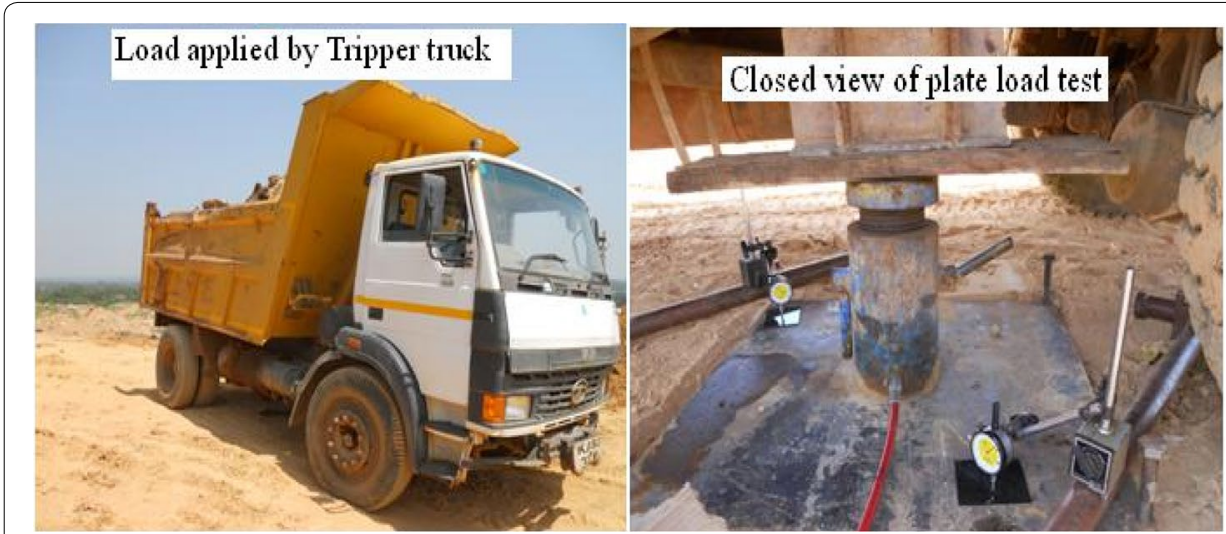

Fig. 15 Typical plate load test setup on the top level of the landfill

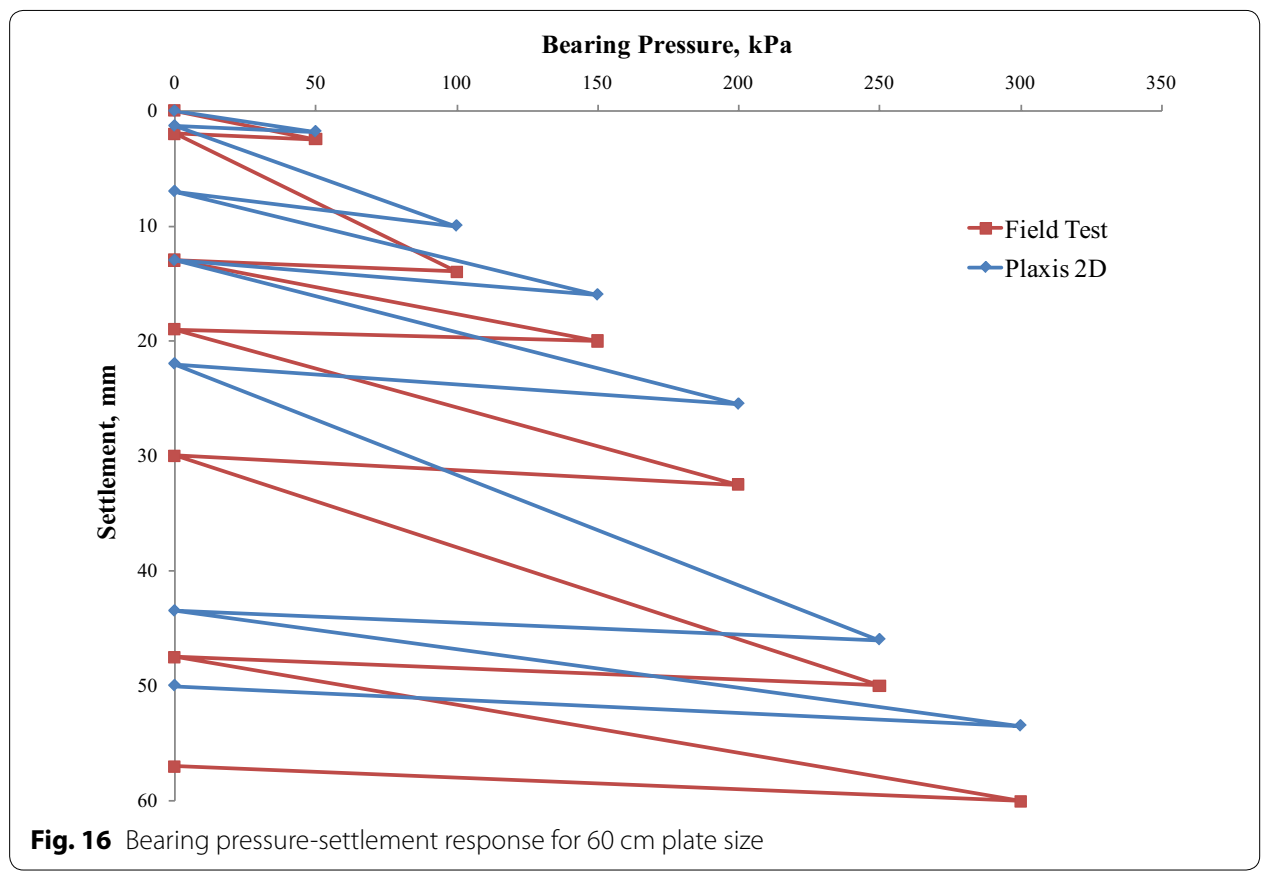

\section{Cyclic plate load test}

Cyclic plate load tests are carried out as per the ASTM D [36]. Tests were carried out on $600 \mathrm{~mm}$ square plate. The load on the test plate was applied through a tipper truck in increments of $250 \mathrm{kPa}$ (Fig. 15). After recording the final settlement at each stage, the plate was unloaded completely, and the subsequent elastic rebound of the plate was measured by means of dial gauges.

From Fig. 16, we can find that the curve obtained using PLAXIS 2D simulations is close to field test results. The failure occurred in 5th load increment itself. The maximum bearing capacity of $250 \mathrm{kPa}$ was observed. The elastic rebound of the footing plate was recorded at every loading and unloading cycle. 


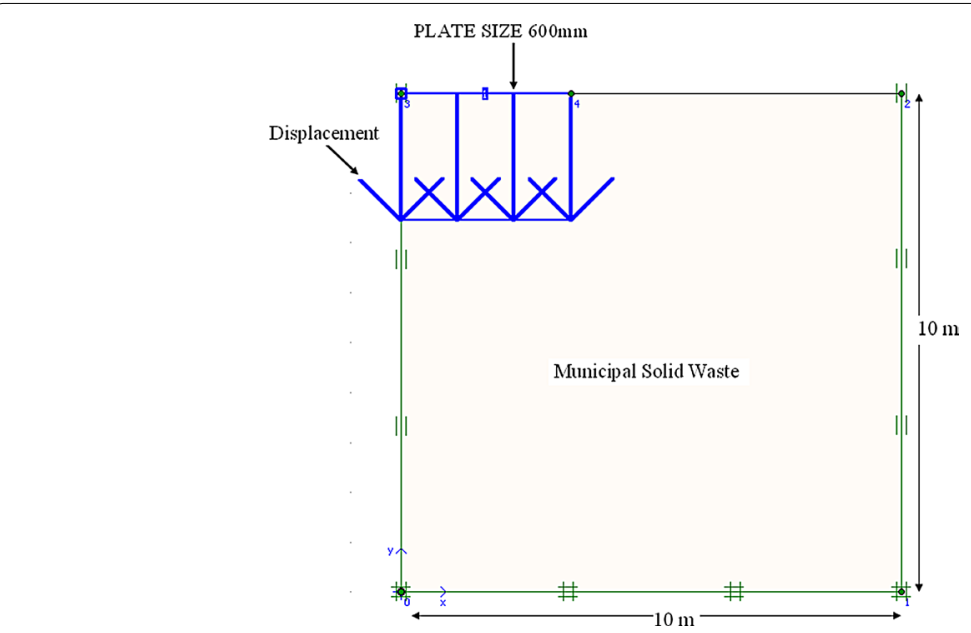

Fig. 17 Model with applied displacement

Table 7 Input MSW layer strength parameters

\begin{tabular}{lc}
\hline $\begin{array}{l}\text { Material } \\
\text { Model }\end{array}$ & Layer \\
& MSW \\
& Soft Soil \\
\hline Weight, $\gamma\left(\mathrm{kN} / \mathrm{m}^{3}\right)$ & 7.00 \\
Cohesion, $C_{\mathrm{ref}}\left(\mathrm{kN} / \mathrm{m}^{2}\right)$ & 10.00 \\
Friction angle, $\varnothing\left(^{\circ}\right)$ & 15.00 \\
EA of plate $(\mathrm{kN} / \mathrm{m})$ & $1.800 \mathrm{E} 09$ \\
El of plate $\left(\mathrm{kNm}{ }^{2} / \mathrm{m}\right)$ & 7812.500
\end{tabular}

\section{Numerical simulations using PLAXIS-2D}

To examine the cyclic plate load tests, in this paper, the load settlement responses of vertically loaded footings placed on municipal solid waste were analyzed using finite element program. The numerical simulations were performed using PLAXIS 2D, version 9, has been used to model a cyclic plate load test. The plate size is $600 \mathrm{~mm}$ and $25 \mathrm{~mm}$ thick. The axisymmetric approach had been selected in the simulations (Fig. 17). The municipal solid waste profiles and parameters used in the simulations were based on in situ tests. The soft soil model was used as a material model to analyse the waste behaviour. Finally, the bearing pressure-settlement curves obtained from finite element simulations were compared with those from in situ cyclic plate-load tests and see whether they are well fitted. Table 7 shows the physical and mechanical properties of the municipal solid waste layer.

From the in situ cyclic bearing pressure-settlement response, the elastic rebound was calculated for each plate load test. The elastic rebound was plotted against the bearing pressure for the different plate size as shown in Fig. 18. The slope of this curve is referred to as the coefficient of elastic uniform compression $\left(C_{u}\right)$. From the $\mathrm{C}_{\mathrm{u}}$, the other elastic constants were evaluated. These elastic constants have the major 


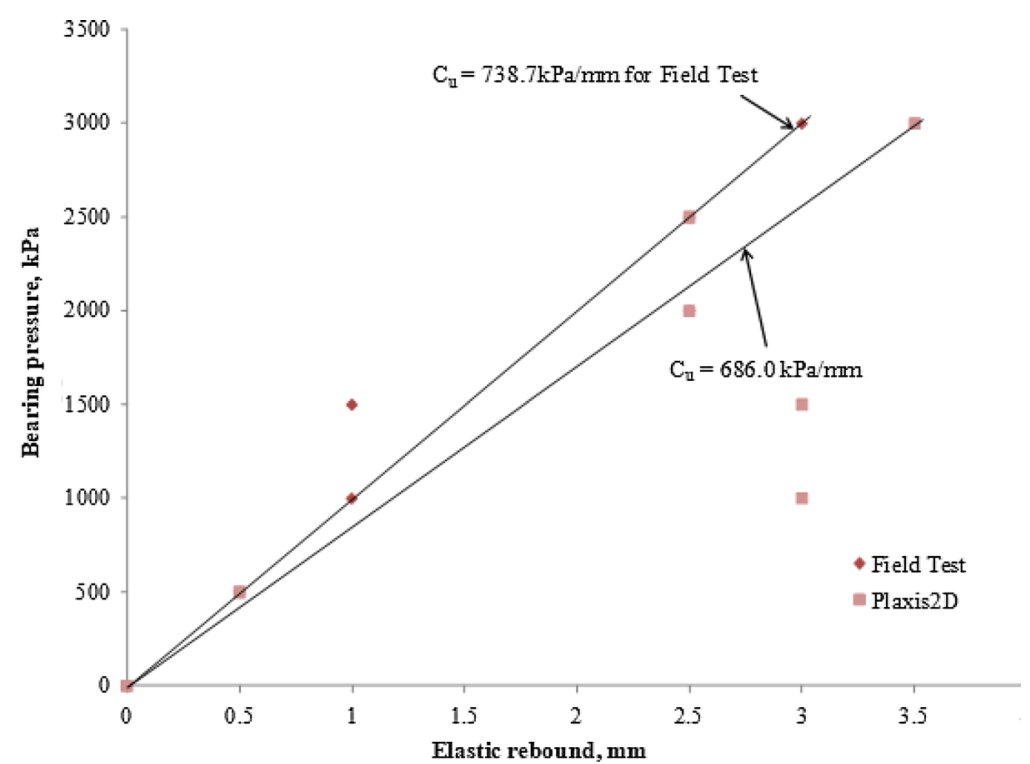

Fig. 18 Bearing pressure vs. elastic rebound for $60 \mathrm{~cm}$ plate size

Table 8 The elastic constants obtained from triaxial test

\begin{tabular}{llc}
\hline Cyclic plate load test & E (GPa) & G (GPa) \\
\hline In-situ & 0.35 & 0.137 \\
PLAXIS 2D & 0.33 & 0.127 \\
\hline
\end{tabular}

importance in the design of the machine foundations. From the in situ cyclic plate load test, elastic constants were found to be $738.7 \mathrm{kPa} / \mathrm{mm}$ and $686 \mathrm{kPa} / \mathrm{mm}$ for PLAXIS 2D.

The value of dynamic shear modulus, $G$ is important parameter in the seismic response analysis of MSW landfill deposit during an earthquake is established from the values of elastic uniform compression $\left(C_{u}\right)$ using the following relations,

$$
\mathrm{G}=\left((1-\mu) \mathrm{C}_{\mathrm{u}} \sqrt{ } \mathrm{A}\right) / 2.26
$$

where $\mu=$ Poisson's ratio; $C_{u}=$ elastic uniform compression; $A=$ area of the plate size

$$
\mathrm{E}=2 \mathrm{G}(1+\mu)
$$

$\mathrm{E}=$ Young's modulus.

Table 8 clearly indicated that the in situ elastic constants shows slightly higher value when compared with PLAXIS 2D.

\section{Interpretation of test results}

The shear modulus is affected by number of parameters such as, the shear strain amplitude, confining pressure, and the density are the important. Since the confining pressure and order of strain level associated with different in situ tests are different, hence tests may be expected to show a wide variation, as the strain associated with, MASW testing 
and ultrasonic test is very small strain and that the with cyclic triaxial and cyclic plate load test is very large strain. Hence, rational approach is needed to arrive at a suitable design value (Bharat Bhushan Prasad [37]).

$$
\mathrm{G}_{1} / \mathrm{G}=\left(\sigma_{01} / \sigma_{0}\right)^{\mathrm{m}}
$$

where G1 and G is dynamic shear modulus for the prototype and from the field test. $\sigma_{01}$, $\sigma_{0}$ is mean effective confining pressure, associated with prototype foundation and the in situ test; $\mathrm{m}$ is the constant depending upon the type of MSW, etc.

Suppose, in the situations where the high strains levels are associated as in the case of seismic response analysis of MSW landfill conditions, the effect of strain level shall be considered along with that of the confining pressure. The value of dynamic shear modulus from various field tests may first be reduced to the same confining pressure and their different strain levels may be achieved at an appropriate value corresponding to the expected strain level.

\section{Conclusions}

The range of variation of geotechnical properties for the analysis of MSW landfill/reclamation was estimated by various laboratory and field tests were reasonable accuracy. Based on the MASW testing data, laboratory cyclic triaxial test, ultrasonic test and field cyclic plate load test data, variation of dynamic properties with strain level. This can be used for carrying out seismic ground response analysis of the MSW landfill site. Major conclusions of this paper are as follows.

- The static and dynamic testing methods are the two main types of tests that are periodically used to assess the properties of MSW. The static test is conducted at low strain and takes longer time than the dynamic test, which is conducted at considerably higher strain.

- It can be concluded that there is good comparison of bearing pressure-settlement relation obtained through in situ cyclic plate load test and that obtained by numerical methods.

- The MASW were implemented to measure shear wave velocity profiles in Mavallipura landfill. These methods are attractive as they are non-instructive, reliable and efficient. These methods were capable of estimating shear wave velocity profile of MSW up to $23.7 \mathrm{~m}$ depth. Based on MASW survey, the site characterization at Mavallipura landfill site, it was found that the landfill site can be categorized as very loose and it is still in a degradation process.

- Based on NEHRP classification system, the site type E corresponds to soft material and average shear wave velocity would be $<180 \mathrm{~m} / \mathrm{s}$.

Authors' contributions

The author read and approved the final manuscript.

Competing interests

The author declares that he/she has no competing interest.

\section{Publisher's Note}

Springer Nature remains neutral with regard to jurisdictional claims in published maps and institutional affiliations. 
Received: 1 September 2018 Accepted: 9 November 2018

Published online: 11 December 2018

\section{References}

1. Koelsch F, Fricke K, Mahler C, Damanhuri E (2005) Stability of landfills, the Bandung dumpsite disaster. In: Proceedings of the 10th international landfill symposium

2. Merry SM, Kavazanjian E, Fritz WU (2005) Reconnaisance of the July 10 2000, Payatas landfill failure. ASCE J Perform Constr Facil 19:100-107

3. Eid HT, Stark TD, Douglas WD, Sherry PE (2000) Municipal Solid waste slope failure 1. Waste and foundation properties. J Geotech Geoenviron Eng ASCE 126(5):397-407

4. Zekkos D, Bray JD, Riemer MF (2008) Shear modulus and material damping of municipal solid waste based on largescale cyclic triaxial testing. Can Geotech J 45(1):45-58

5. Hardin BO, Black WL (1968) Vibration modulus of normally consolidated clay. J Soil Mech Found Div ASCE 94(2):353-368

6. Peacock WH, Seed HB (1968) Sand liquefaction under cyclic loading simple shear conditions. J Soil Mech Found Div Am Soc Civ Eng 94(SM-3):689-708

7. Seed HB, Idriss IM (1970) Soil moduli and damping factors for dynamic response of analyses. Report No. EERC 70-10, Earthquake Engineering Research Centre, University of California

8. Dyvik R, Madshus C (1985) Lab measurement of Gmax using bender elements. Norwegian Geotechnical Institute, Oslo, Norway. Publication No. 161, pp 186-196

9. Vucetic M, Dobry R (1991) Effect of soil plasticity on cyclic response. J Geotech Eng ASCE 117:89-107

10. Darendeli BM (2001) Develop of a new family of normalized modulus reduction and material damping curves. Ph.D. Dissertation, The University of Texas at Austin

11. Nazarian S, Stokoe KH II (1984) In situ shear wave velocities from spectral analysis of surface waves. In: Proceedings of eighth world conference on earthquake engineering, San Fransisco, CA, vol III, pp 31-38

12. Cox B (2006) Development of a direct test method for dynamically assessing the liquefaction resistance of soil in situ. Ph.D. Dissertation, The University of Texas at Austin, U.S.A. pp 497

13. Rosenblad BL, Li J, Menq F-Y, Stokoe KH II (2007) Deep shear wave velocity profiles from surface wave measurements in the Mississippi embayment. Earthq Spectra EERI 23(4):791-809

14. Zeiss C, Major W (1992) Moisture flow through municipal solid waste; patterns and characteristics. J Environ Syst 23(3):211-231

15. Beaven R, Powrie W (1996) Determination of the hydrogeological and geotechnical properties of refuse in relation to sustainable landfilling. In: Proceedings of the nineteenth international Madison waste conference: municipal and industrial waste, University of Wisconsin, Madison, Madison, WI, pp 435-453

16. ASTM D 845 (1999) Standard test methods for specific gravity of soil solids by water pycnometer. ASTM International, Philadelphia

17. Yesiller N, Hanson J, Cox JT, Noce DE (2014) Determination of specific gravity of municipal solid waste. Waste Manag 34(5):848-858

18. Breitmeyer RJ (2011) Hydraulic characterization of municipal solid waste. Ph.D. Dissertation, University of WisconsinMadison, Madison, WI

19. ASTM D-422 (1998) Standard test method for particle-size analysis of soils. Annual Book of ASTM Standards. American Society for Testing and Materials, West Conshohocken

20. ASTM D-698 (1998) Standard test methods for laboratory compaction characteristics of soil using standard effort. Annual Book of ASTM Standards. American Society for Testing and Materials, West Conshohocken

21. Harris MRR (1979) Geotechnical characteristics of landfilled domestic refuse, the engineering behaviour of industrial and urban fill. In: Proceeding of the symposium held at the University of Birmingham, Midland Geotechnical Society, University of Birmingham, Birmingham, England, pp B1-B10

22. ASTM D-2434 (1998) Standard test method for permeability of granular soils (constant head). Annual Book of ASTM Standards. American Society for Testing and Materials, West Conshohocken

23. Penmethsa KK, Hossain S (2007) Permeability of municipal solid waste in bioreactor landfill with degradation. Master of Science of civil engineering, The University of Texas at Arlington

24. Korman EM, Horvitz EG, Kleppe HJ, Dalton GM (1987) Material properties of Landfilled primary waste, In: Environmental conference: Portland Marriott, Portland, April 27-29, pp 179-186

25. ASTM D 4546 (2008) Standard test methods for one-dimensional swell or collapse of cohesive soils. ASTM International, West Conshohocken

26. Reddy KR, Hettiarachchi H, Gangathulasi J, Bogner JE, Lagier T (2009) Geotechnical properties of synthetic municipal solid waste. Int J Geotech Eng 3:429-438

27. Hossain MS (2002) Mechanics of compressibility and strength of solid waste in bioreactor landfills. Doctoral Thesis, North Carolina State University at Raleigh

28. ASTM D 3080 (1998) Standard test method for direct shear test of soils under consolidated drained conditions. ASTM, Philadelphia

29. Gabr MA, Valero SN (1995) Geotechnical properties of municipal solid waste. Geotech Test J 18(2):241-255

30. Grisolia M, Napoleoni Q, Tancedi G (1995) The use of triaxial test for characterization of MSW. In: Proceedings of Sardinia 95-5th international waste management and landfill symposium, Cagliari, Italy, vol II, pp 761-768

31. Tony LTZ, Chen YM, Ling WA (2007) Shear strength characterization of municipal solid waste at the Suzhou landfill, China. Eng Geol 97:111

32. Howland J, Landva AO (1992) Stability analysis of a municipal solid waste landfill. In: Stability and performance of slopes and embankments-II, ASCE Geotechnical Special Publication No. 31, pp 1216-1231 
33. ASTM D 2845 (2005) Standard test method for laboratory determination of pulse velocities and ultrasonic elastic constants of rock. ASTM International, West Conshohocken

34. William Lambe T, Whitman Robert V (1969) Soil mechanics. Wiley, New York

35. Ranjan G, Rao ASR (2002) Basic and applied soil mechanics. Wiley Eastern Ltd, New Delhi

36. ASTM D 1194 (1994) Standard test method for bearing capacity of soil for static load and spread footing. West Conshohocken, ASTM International

37. Prasad BB (2009) Fundamentals of soil dynamics and earthquake engineering. PHI Learning Pvt Ltd, New Delhi

Submit your manuscript to a SpringerOpen ${ }^{\circ}$ journal and benefit from:

- Convenient online submission

- Rigorous peer review

- Open access: articles freely available online

- High visibility within the field

Retaining the copyright to your article

Submit your next manuscript at $\boldsymbol{s p r i n g e r o p e n . c o m ~}$ 